研

究

準結晶を含む急冷 Al-Cr 合金のMGによるアモルファス化とパルス通電焼結によるバルク化

尾崎 公洋, 小林 慶三, 杉山 明, 西尾 敏幸

名古屋工業技術研究所，广 462-8510 名古屋市北区平手町 1-1.

\title{
Amorphization of rapidly solidified Al-Cr alloy with quasicrystal by mechanically grinding and preparing bulk material by pulsed current sintering
}

\author{
Kimihiro Ozaki, Keizo Kobayashi, Akira Sugiyama and Toshiyuki Nishio
}

National Industrial Research Institute of Nagoya, AIST, MITI, 1-1 Hirate-cho Kita-ku, Nagoya 462-8510.

Received July 31, 1998

\section{SYNOPSIS}

An $\mathrm{Al}-\mathrm{Cr}$ amorphous powder prepared by mechanically grinding a rapidly solidified ribbon was consolidated by pulsed current sintering at lower temperature than the crystallization temperature. The rapidly solidified $\mathrm{Al}_{100-\mathrm{x}} \mathrm{Cr}_{\mathbf{x}}$ $(\mathrm{x}=5-15)$ ribbons were prepared by single roll method. The quasicrystalline phase existed in the $7-13 \mathrm{at} \% \mathrm{Cr}$ ribbons. By mechanically grinding, the amorphous phase was formed in the powder of $10-15$ at $\% \mathrm{Cr}$. The analysis by XRD and $\mathrm{DSC}$ revealed that the mechanically ground $\mathrm{Al}_{87} \mathrm{Cr}_{13}$ and $\mathrm{Al}_{85} \mathrm{Cr}_{13}$ powders were a single amorphous phase. $\mathrm{Al}_{90} \mathrm{Cr}_{10}$ powder consisted of the $\mathrm{Al}$ phase and the amorphous phase. A disk specimen of $10 \mathrm{~mm}$ in diameter was prepared by sintering at $500 \mathrm{MPa}$ pressure at $573 \mathrm{~K}$ with a hard metal die. The consolidated $\mathrm{Al}_{90} \mathrm{Cr}_{10}$ had the porosity of $3.3 \%$, while $\mathrm{Al}_{87} \mathrm{Cr}_{13}$ had the porosity of $20.7 \%$. The marked difference between them is resulted from the mass flow of the $\mathrm{Al}$ in the $\mathrm{Al}_{90} \mathrm{Cr}_{10}$ sample to the triple points among the particles.

\section{KEY WORDS}

$\mathrm{Al}-\mathrm{Cr}$ amorphous alloy, spark plasma sintering, super-saturated solid solution, sintering ability

\section{1 緒言}

アモルファスや準結晶のような非平衡状態にある材料を強度 材料として使用するための研究が行われている。特に $\mathrm{Al}$ 基の 非平衡状態材料は軽量高強度材料として注目されている。AJ$\mathrm{Cr}-\mathrm{Ce}$ 合金の急冷凝固りボンについては1300MPaという強度を 持つことが報告されている゙!これは，数十 $\mathrm{nm}$ サイズの準結 晶粒子と $\mathrm{Al}$ が混在した組織を有し，準結晶粒界に $\mathrm{Al}$ が存在す ることにより, 強度が高くなると述べられている.さらに，こ のような状態の粉末をアトマイズによって作製し,これを押し 出し成形することによってバルク材料を作製し，その強度は 670MPa と報告されている2).一方，Al-Cr合金はメカニカルア ロイング (MA)あるいはメカニカルグライディング (MG)に よってアモルファス状態になることが報告されている3 ${ }^{3,4)}$.この MAにより作製した $\mathrm{Al}_{85} \mathrm{Cr}_{15}$ 組成の粉末を熱間圧延することに よって，板状のアモルファスバルク材が作製されており")，そ の硬度は元の粉末とほとんど同じ $450 \mathrm{Hv}$ を示している.

このようなアモルファス合金に代表される非平衡状態にある 材料は熱的に不安定で,加熱による構造変化により本来の特性
が失われる.したがって,アモルファス粉末からバルク体を作 製する場合, 結晶化温度以下で固化する手法を開発する, ある いは低温で固化可能な粉末を作製する必要がある。本研究で は,焼結性の良いアモルファス粉末をMGにより作製し, 粉末 固化法としてパルス通電焼結法 (放電焼結法) を用いてアモル ファスバルク材の作製を試みた。急冷凝固 $\mathrm{Al}_{100-\mathrm{x}} \mathrm{Cr}_{\mathbf{x}}(\mathrm{x}=5-15)$ 合 金について，これらをMGすることによりアモルファス相の現 れる組成範囲を調べた.さらにその中でアモルファス相を持つ 粉末をパルス通電焼結法によって結晶化温度以下で焼結し,粉 末の状態が焼結性におよぼす影響を調べた。

\section{2 実験方法}

単ロール急冷法により, $\mathrm{Al}_{100-\mathrm{x}} \mathrm{Cr}_{\mathrm{x}}(\mathrm{x}=5-15)$ の急冷リボンを作 製した.日新技研製の単ロール急冷装置を用い, ロール回転数 は5000r.p.m., チェンバー内は真空引き後Ar置換によって減圧 (74.7kPa) Ar雲囲気，噴射ガス圧は $68.6 \mathrm{kPa} の$ 条件にて使用し た.噴射ノズルは，Alと石英ガラスの反応を避けるため，先端 に直径0.6mmの穴をあけたグラファイト製ノズルを使用した。 
ロールとノズル先端の間隔は $0.4 \mathrm{~mm}$ で行った。作製された急 冷りボンを振動型ボールミル装置(日新技研製スーパーミスニ) にて MGを行った、MGにはSUS製容器および直径 $10 \mathrm{~mm} の$ SUS304製ボールを使用し，ボール充填率 $16.3 \%$ ，粉末重量対 ボール重量の比は $1: 74$ とした. 容器内を真空に引いた後 $\mathrm{Ar}$ 置換し, 大気圧Ar中でミリングを行った。作製した MG 粉末 をパルス通電焼結装置(住友石炭鉱業製SPS-510L)によって真 空中 (13.3Pa) で焼結した.ダイセットとして直径 $10 \mathrm{~mm}$ の超 硬製を用い，この内側には離型材である BN 粉末をスプレー して使用した．超硬製のダイだけでは温度が上昇しなかった ため, 加熱補助としてパンチと粉末の間にカーボンシートを 挟んだ. 加圧力 $500 \mathrm{MPa}$ で, 厚さ2 7 $7 \mathrm{~mm}$ のディスク状試料を 作製した。急冷りボン，粉末および固化試料は，示差走查熱 量計 (DSC) (島津製作所製)，X線回折装置 (XRD) (島津製作 所製), 走查電子顕微鏡 -エネルギー分散型 $\mathrm{X}$ 線分析装置 (SEM-EDX) (日立製作所 一堀場製作所製)，光学顕微鏡 (ニコ ン製)を用いて,それそれの構造および組織変化を調べた。ま た硬度をマイクロビッカース硬度計によって測定した。焼結 体の空孔率は，光学顕微鏡による画像をコンピュータに取り 込み，画像処理することによって求めた。

\section{3 実験結果および考察}

$3.1 \mathrm{Al}-\mathrm{Cr}$ 急冷凝固粉のアモルファス化

单ロールによって急冷した合金はFig.1のXRD結果に示す ように，Cr量が7〜13at\%の間で準結晶を含む組織相が生成さ れた。 $\mathrm{Al}_{95} \mathrm{Cr}_{15}$ においては，Alよりわずかに高角側にあるピー クが見られる.これは，急冷によって生成された Al-Cr固溶体

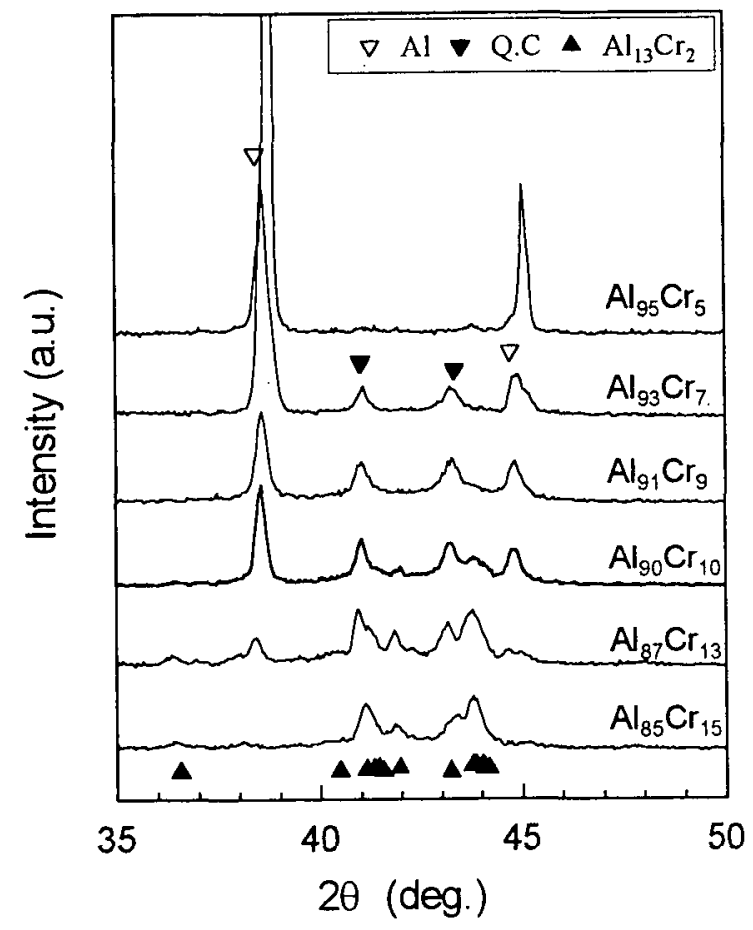

Fig.1 XRD patterns of rapidly solidified Al-Cr alloys by single roll method.
であると考えられる， $\mathrm{Al}_{85} \mathrm{Cr}_{15}$ においては，金属間化合物 $\mathrm{Al}_{13} \mathrm{Cr}_{2}$ と $\mathrm{Al}_{5} \mathrm{Cr}$ の混合組織，10〜13at\% $\mathrm{Cr}$ では $\mathrm{Al}$ 相， $\mathrm{Al}_{13} \mathrm{Cr}_{2}$ および準結晶相の混成組織，9〜7at\%Crでは Al 相および準結 晶相となる。 10〜13at $\% \mathrm{Cr}$ では準結晶のピークと金属間化合 物のピーク強度が相反して变化し， C $\mathrm{r}$ 量が減少するに従い準 結晶ピークが相対的に高くなる.これらの結果は，すでに報 告されている結果6)と一致する部分もあるが，準結晶が生成 されると報告されている $\mathrm{Al}_{85} \mathrm{Cr}_{15}$ に関しては異なっている.こ れは，本実験で使用した単ロール装置の性能によるものであ ると思われる，すなわち，本装置の冷却速度が遅いため，他 の組成より融点が高い $\mathrm{A}_{85} \mathrm{Cr}_{15}$ 組成では準結晶化しなかったも のと予想される。これらの急冷凝固りボンを $720 \mathrm{ks}$ 間 MG L て作製した粉末のX線回折結果を Fig.2に示す. Al 量が94at\% 以上になるとミリング容器およびボールへの付着が多く，粉 末としてほとんど回収できなかった. $\mathrm{Al}_{85} \mathrm{Cr}_{15}$ および $\mathrm{Al}_{87} \mathrm{Cr}_{13}$ 組 成においては，MGによってアモルファス状のブロードな回 折結果が得られる. $\mathrm{Al}$ 量の增加に従って，アモルファス相に 加え Al相の存在を示すピークが観察される. Alが93at\%以上 になるとブロードなピークは見られなくなり，Alのピークの みか観察されるようになる. Alが 90\%以上の組成で見られる Alのピークは，純Alのピークから高角側にずれており，過飽 和固溶体を形成していることがわかる。すなわち，Alが91at\% 以上の場合はMGによって準結晶が分解し AI 中に強制固溶す る.また, $\mathrm{Al}_{85} \mathrm{Cr}_{15}$ あるいは $\mathrm{Al}_{87} \mathrm{Cr}_{13}$ に見られるように金属間 化合物がアモルファス化することから，Alが90at\%の時は準 結晶は $\mathrm{Al}$ に強制固溶し，金属間化合物の一部または全部がア モルファス化したと考えられる.このX線回折的にアモル

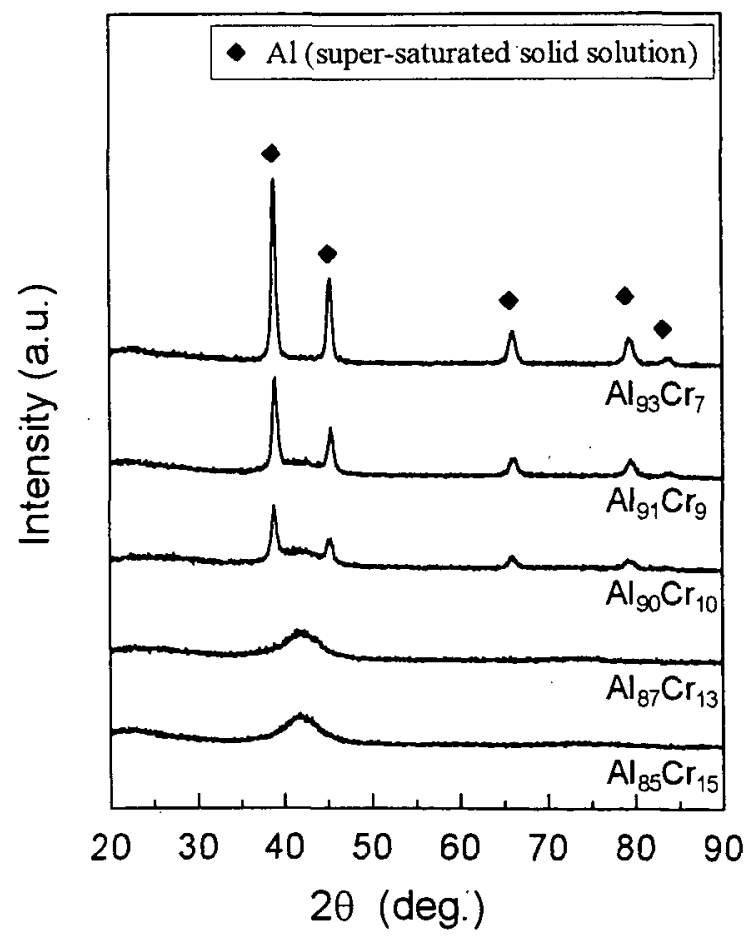

Fig.2 XRD patterns of mechanically ground $\mathrm{Al}-\mathrm{Cr}$ powder. The milling time is $720 \mathrm{ks}$. 
ファス相が存在する $\mathrm{Al}_{90} \mathrm{Cr}_{10}, \mathrm{Al}_{87} \mathrm{Cr}_{13}$ および $\mathrm{Al}_{85} \mathrm{Cr}_{15}$ の $\mathrm{MG}$ 粉末 について, DSCにより熱特性を調べた結果をFig.3に示す。い ずれも, $630 \mathrm{~K} て ゙$ 発熱反応が見られるが, $\mathrm{Al}_{90} \mathrm{Cr}_{10}$ の場合の発熱 が他の組成より大きくなっていることがわかる.この $\mathrm{Al}_{90} \mathrm{Cr}_{10}$ の MG 粉末を発熱反応より高温の 773Kで熱処理し，XRDに よって構造を調べた結果, 金属間化合物の発生とともに $\mathrm{Al}$ 過 飽和固溶体を示すピークが純Alの位置に移動していることが

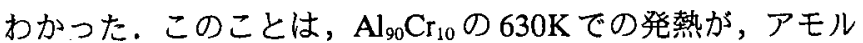

milling time : $720 \mathrm{ks}$



Fig.3 DSC curves of mechanically ground $\mathrm{Al}_{85} \mathrm{Cr}_{15}, \mathrm{Al}_{87} \mathrm{Cr}_{13}$ and $\mathrm{Al}_{90} \mathrm{Cr}_{10}$ powder. The $\mathrm{T}_{x}$ and the $\mathrm{T}_{\mathrm{mAl}}$ indicate the crystallization temperature and the melting point of $\mathrm{Al}$.

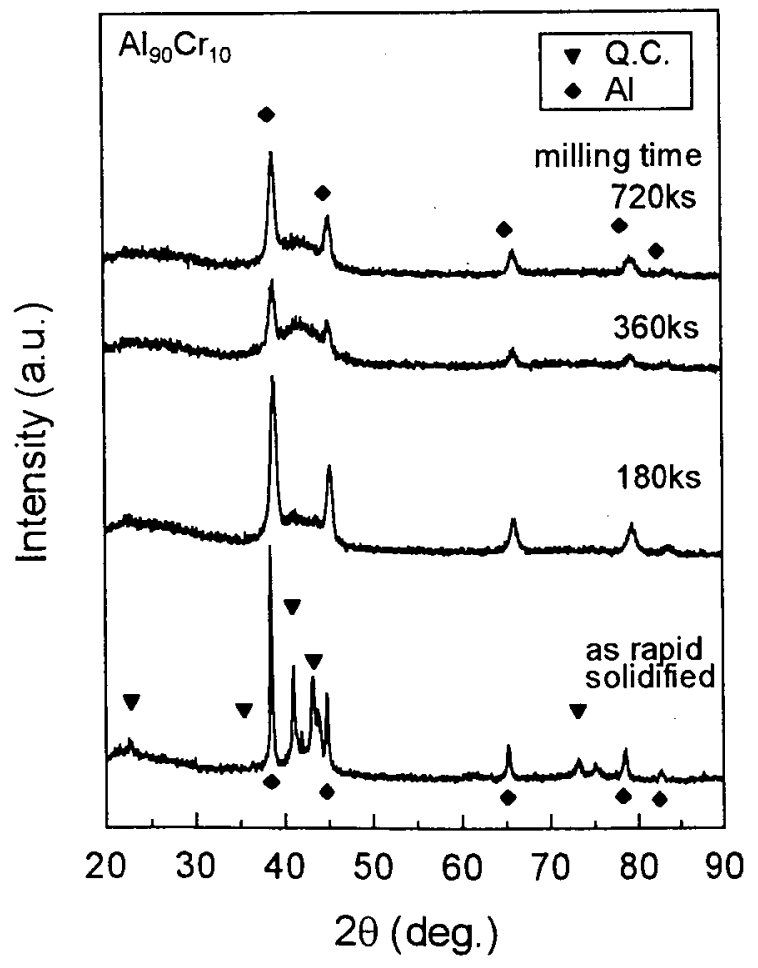

Fig.4 XRD patterns of mechanically ground $\mathrm{Al}_{90} \mathrm{Cr}_{10}$ for various milling times.
ファス相の結晶化に伴う発熱と過飽和固溶体が金属間化合物 になる際の発熱が合わさったものであることを示している.

$\mathrm{Al}_{90} \mathrm{Cr}_{10}$ 急冷リボンを $\mathrm{MG}$ した場合のミリング時間による XRD パターンの変化を Fig.4に示す.急冷されたリボンはAJ と準結晶およびわずかな金属間化合物で構成されている.ミ リング時間の経過に伴って，準結晶を示すピークおよび金属 間化合物を示すピークが減少し，360ksミリングするとアモル ファス状のブロードな曲線が現れる。また，Al相もミリング に伴ってピーク強度の低下が見られるが, $720 \mathrm{ks}$ 経過後もピ一 クが観察でき， $\mathrm{Al}$ 相が存在していることがかかる。しかし， 180ksの MGによってすでに Al 相のピークは純 $\mathrm{Al}$ のピーク位 置に比べ高角度側にシフトしている。これは，先に述べたよ うにAl相に不純物元素が過飽和となっていることを示してい る.これらの MG 粉末の DSC 测定結果を Fig.5に示す. 急冷 された状態の粉末では，650Kで準結晶の安定化に伴う発熱反

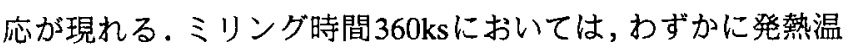
度の違う2種類の発熱が重なるように現れ，720ksのMGにお いて, 準結晶の発熱温度よりわずか $20 \mathrm{~K}$ 程度低い630Kの発熱 反応のみが現れる。先に述べたように，この発熱はアモル ファスの結晶化と過飽和固溶体の安定化との混合の発熱反応 であると考えられる。

\section{2 パルス通電焼結によるバルク化}

先の DSCの結果から， Al-Crアモルファス粉末を焼結する 際には，焼結温度を $630 \mathrm{~K}$ 以下で行う必要がある。そこで， 720ks の MGによってアモルファス相を形成した $\mathrm{Al}_{87} \mathrm{Cr}_{13}$ およ び $\mathrm{Al}_{90} \mathrm{Cr}_{10}$ 粉末をパルス通電焼結法にて加圧力 $500 \mathrm{MPa}$ ，燒結

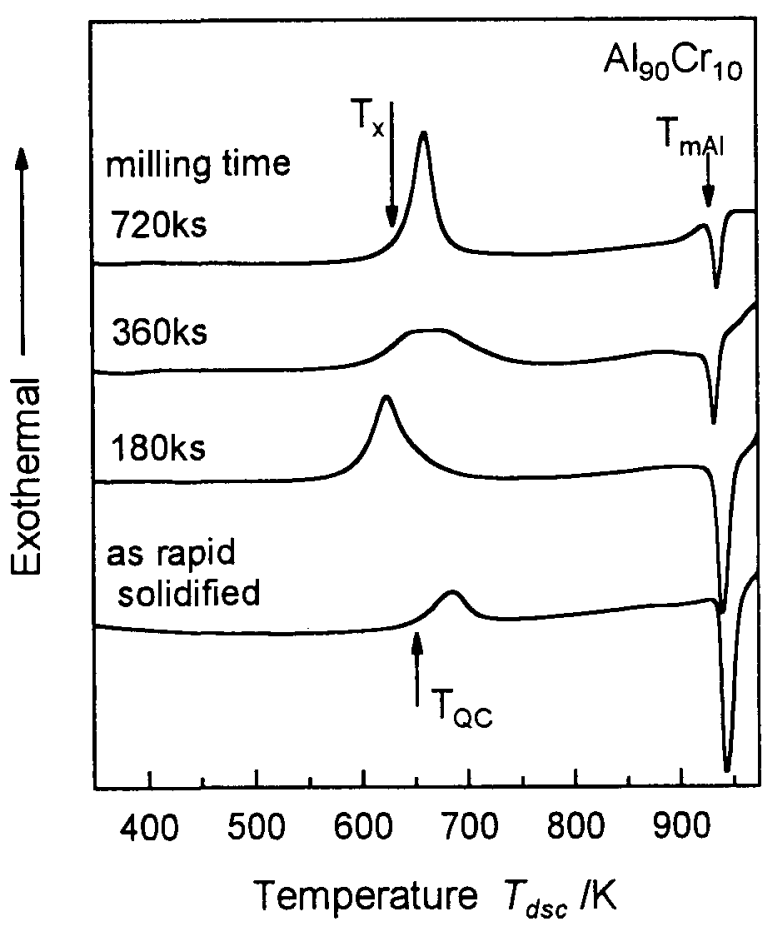

Fig.5 DSC curves of mechanically ground $\mathrm{Al}_{90} \mathrm{Cr}_{10}$ powder for various milling times. The DSC curves are obtained at the heating rate of $0.33 \mathrm{~K} / \mathrm{s}$. 
温度 $573 \mathrm{~K}$, 焼結時間 1200 sで焼結した. $\mathrm{Al}_{90} \mathrm{Cr}_{10}$ 粉末の焼結中 の収縮曲線をFig.6に示す.この図は加圧方向における収縮量 の加熱中の温度依存性および573Kで保持中の時間依存性を示 している.この収縮量は粉末とダイの加圧方向の全体の変位 を測定しているため, 加熱直後はダイの膨張により収縮量が 負の值を示している. およそ $480 \mathrm{~K}$ から収縮を開始し, 保持温 度 $573 \mathrm{~K}$ まで収縮する. 573Kで保持中も時間の経過とともに 収縮している. このことは, 保持時間を長くすることによっ て焼結が進んでいることを示している. 焼結終了後の試料厚 さは約 $2 \mathrm{~mm}$ であった. 焼結した $\mathrm{Al}_{85} \mathrm{Cr}_{15}$ および $\mathrm{Al}_{90} \mathrm{Cr}_{10}$ 試料の 断面の光学顕微鏡像を Fig.7 に示す. $\mathrm{Al}$ 相を含む $\mathrm{Al}_{90} \mathrm{Cr}_{10}$ 組成 においては, $\mathrm{Al}$ 相を含まない $\mathrm{Al}_{87} \mathrm{Cr}_{13}$ 組成の場合と比較して空
孔が少ないことがわかる.この空孔率を画像処理で測定した 結果 $\mathrm{Al}_{90} \mathrm{Cr}_{10}$ 組成の場合 $3.3 \%$ となり $\mathrm{Al}_{87} \mathrm{Cr}_{13}$ の $20.7 \%$ に比較し て小さくなることから, Al 相を含む粉末の焼結性が向上して いることがわかる. $\mathrm{Al}_{90} \mathrm{Cr}_{10}$ の MG 粉末と焼結後の試料の XRD 結果を Fig.8に示す. 焼結試料の XRD によると, 金属間化合 物がわずかに析出してきているもののアモルファスを示すブ ロードなピークが得られている. また, MG 粉末では, $\mathrm{Al} の$

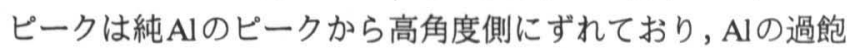
和固溶体を作っているが, 焼結試料は $\mathrm{Al}$ の過飽和固溶体の ピークとともに $\mathrm{Al}$ のピークがわずかに観察できる. MG 粉末 を狫結と同じ温度 $573 \mathrm{~K}$ で熱処理しても，このような $\mathrm{Al}$ の ピークは現れないことから, 焼結体に特有の現象である. そ
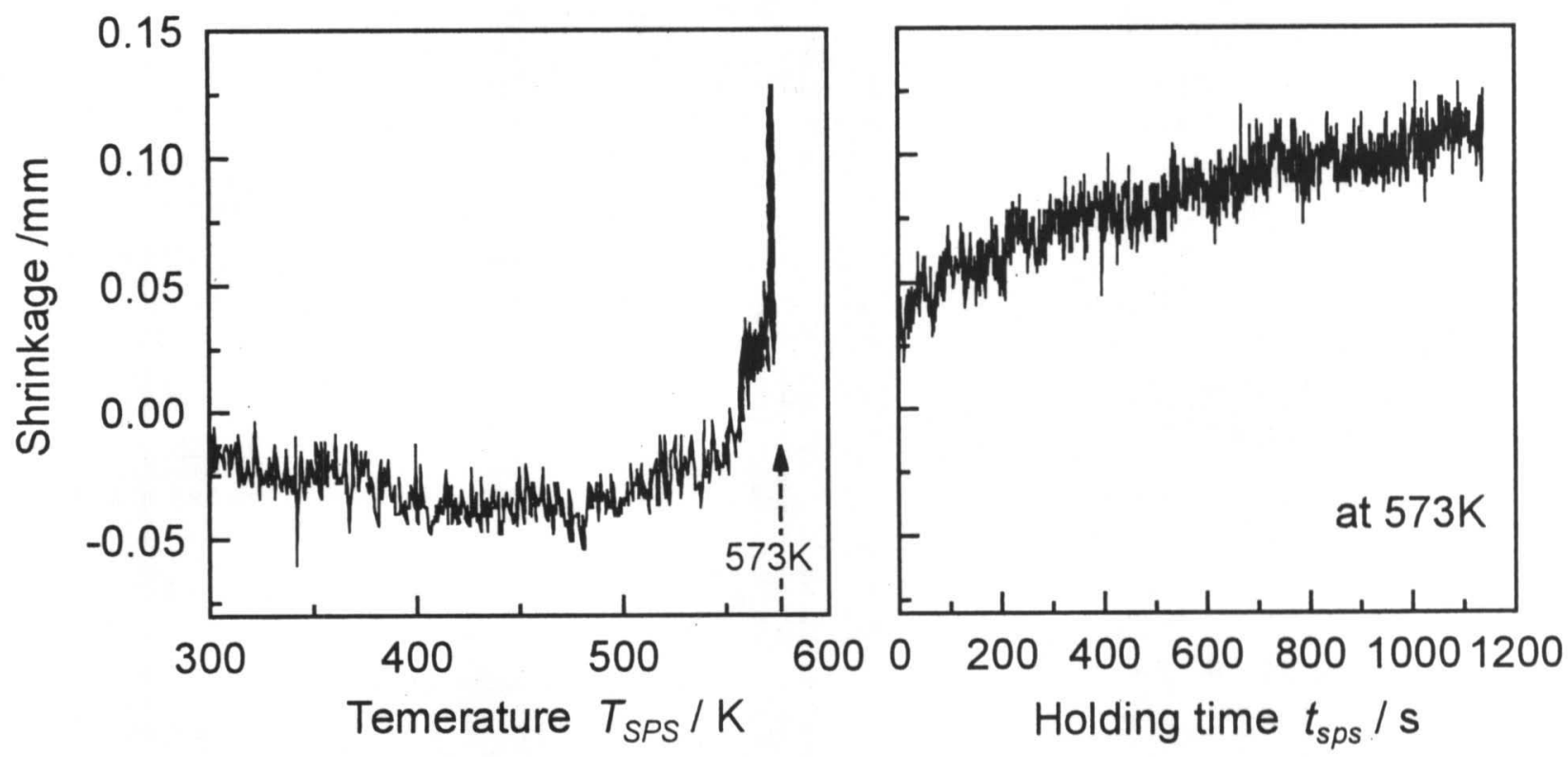

Fig.6 Changes of shrinkage of $\mathrm{Al}_{90} \mathrm{Cr}_{10}$ powder with heating temperature and holding time at $573 \mathrm{~K}$ in the pulse current sintering. The thick of the specimen after sintering is about $2 \mathrm{~mm}$.

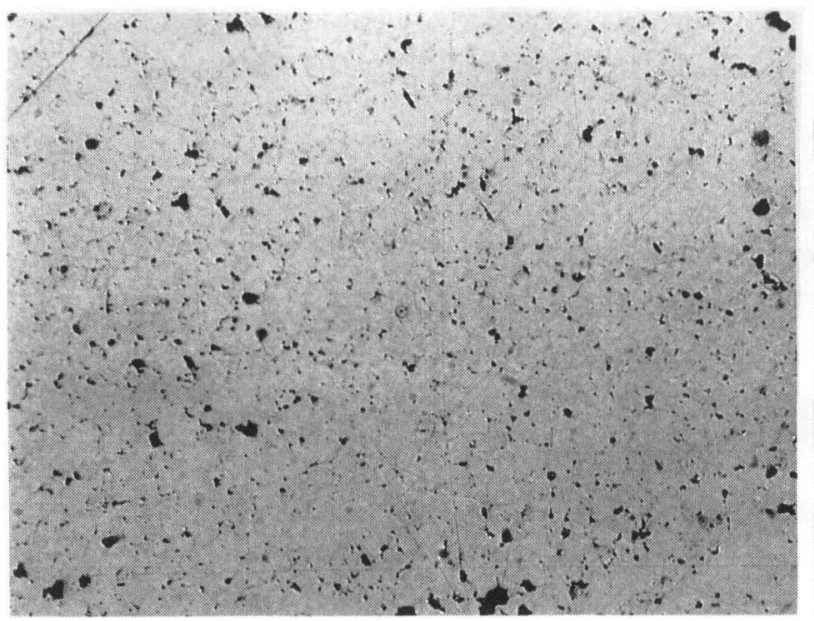

(a) $\mathrm{Al}_{90} \mathrm{Cr}_{10}$

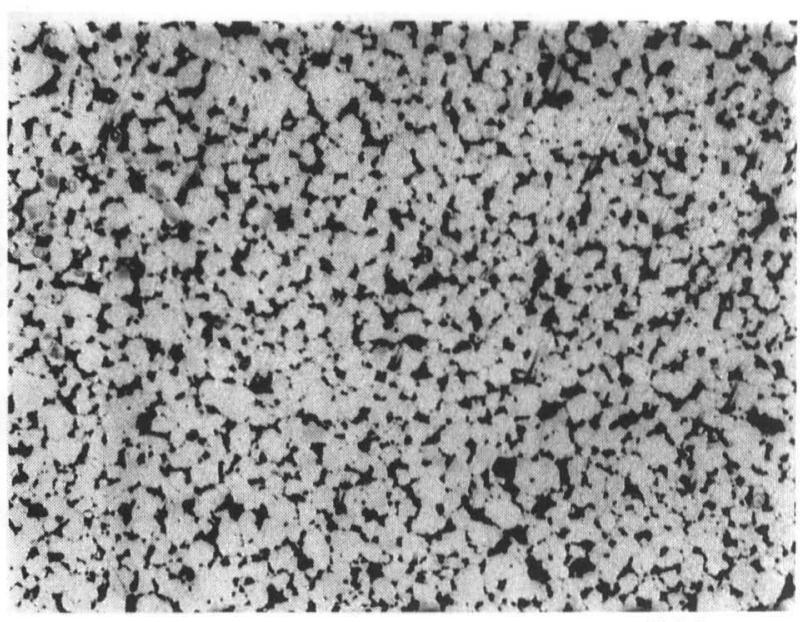

$200 \mu \mathrm{m}$

(b) $\mathrm{Al}_{87} \mathrm{Cr}_{13}$

Fig.7 Optical microscopic images of sintered $\mathrm{Al}_{90} \mathrm{Cr}_{10}$ (a) and $\mathrm{Al}_{87} \mathrm{Cr}_{13}$ (b) specimen. The porosity of $\mathrm{Al}_{90} \mathrm{Cr}_{10}$ and $\mathrm{Al}_{87} \mathrm{Cr}_{13}$ are $3.3 \%$ and $20.7 \%$ respectively. 


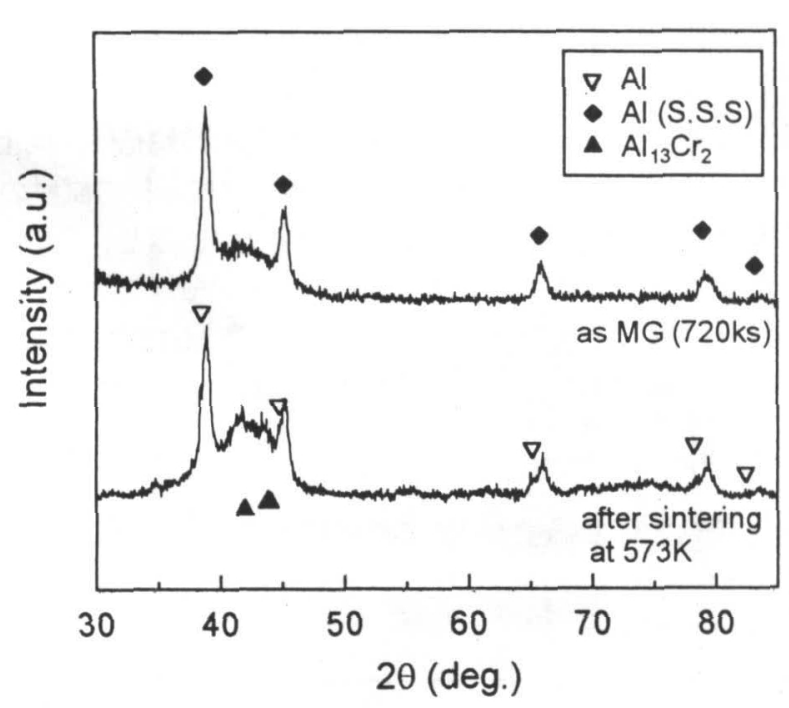

Fig.8 XRD patterns of the powder as MG and the specimen after sintering at $573 \mathrm{~K}$. the $\mathrm{Al}$ (S.S.S) shows super-saturated solid solution of $\mathrm{Al}$.

こで，この焼結体をSEM-EDXによって組成分析した結果を Fig.9 に示す. Al 分析像および $\mathrm{Cr}$ 分析像は, 白い部分ほどそ れぞれの元素の濃度が高くなることを示している. 粒内は $\mathrm{Al}$ および Crの組成が均一であるのに比べ, 粒界の三重点に組成 の異なる部分が存在し.この領域の組成はほとんど $\mathrm{Al}$ 単相で あることがわかる. 焼結前の MG 粉末はSEM-EDXによる分 析結果では,組成はマイクロメートルレベルで均質であった。 このSEM-EDXによる結果とXRDによる結果から, 焼結時に 粉末内に存在した $\mathrm{Al}$ 過飽和固溶体から $\mathrm{Al}$ が粒界に移動した ものと考えることができる.この結果, $\mathrm{Al}$ 相を含む $\mathrm{Al}_{90} \mathrm{Cr}_{10}$ 組 成の MG 粉末を焼結した場合, $\mathrm{Al}$ 相を含まない場合に比べ焼 結密度が向上したものと考えられる. 焼結体の硬度は $482 \mathrm{Hv}$ であり, MG 粉末の $367 \mathrm{Hv}$ より硬くなった. 粒界に析出した $\mathrm{Al}$ 相の影響による軟化は見られず，わずかな金属間化合物の 析出によって硬度が高くなったものと思われる。

\section{4 結 論}

$\mathrm{Al}_{100-\mathrm{x}} \mathrm{Cr}_{\mathrm{x}}(\mathrm{x}=5-15)$ 組成の急冷凝固リボンを $\mathrm{MG}$ するこ とによってアモルファス相の生成を調べた結果, $720 \mathrm{ks}$ の $\mathrm{MG}$ によって $\mathrm{Al}_{85} \mathrm{Cr}_{15}$ および $\mathrm{Al}_{87} \mathrm{Cr}_{13}$ 組成においてアモ ルファス単相が, $\mathrm{Al}_{90} \mathrm{Cr}_{10}$ 組成において $\mathrm{Al}$ 相とアモル ファス相の混在する組織が得られた.このMG粉末をパ ルス通電焼結すると,アモルファス単相の焼結体に比べ 空孔率が減少することがわかった。これは, MG粉末内 に含まれる $\mathrm{Al}$ 相が粒界に移動することによって空孔を 減少させるためである.したがって, 低温での焼結が必 要であるためバルク化が困難なアモルファス粉末を $\mathrm{Al}$ 相を含むアモルファス粉末を作製することによって,バ ルク化が容易となった.

\section{文献}

1) A.Inoue, H.M.Kimura, K.Sasamori and T.Masumoto: "Ultrahigh Strength of Rapidly Solidified $\mathrm{Al}_{96-x} \mathrm{Cr}_{3} \mathrm{Ce}_{1} \mathrm{Co}_{x}$ (x=1,1.5 and 2)", Mater. Trans., JIM, 35(1994)85-94.

2) 木村久道, 井上明久, 笹森賢一郎, 河村能人："準結 晶を含むガス噴霧 $\mathrm{Al}-\mathrm{Cr}$ 系合金粉末の押し出し成形 と機械的性質 ", 粉体および粉末治金, 44(1997)858863.

3) K.F.Kobayashi, N.Tachibana and P.H.Shingu: "Formation of amorphous $\mathrm{Al}-\mathrm{Cr}$ alloys by mechanical alloying", J. Mater. Sci., 25(1990)3149-3154.

4) K.F.Kobayashi, N.Tachibana and P.H.Shingu: "Amorphous $\mathrm{Al}-\mathrm{Cr}$ alloys by mechanical grinding of rapidly solidified", J. Mater. Sci., 25(1990)801-804.

5) K.Uenishi and K.F.Kobayashi: "Fabrication of bulk amorphous alloy by rolling of mechanically alloyed", Mater. Sci. and Eng., A181/A182(1994)1165-1168.

6) A.Inoue, H.Kimura and T.Masumoto: "Formation, thermal stability and electrical resistivity of quasicrystalline phase in", J. Mater. Sci., 22(1987)1758-1768.

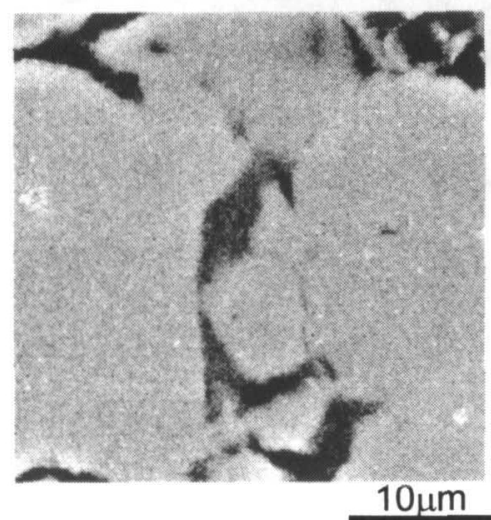

(a) SEM

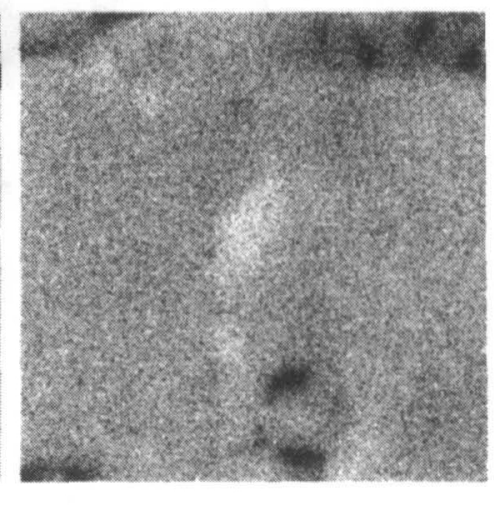

(b) $\mathrm{Al}$

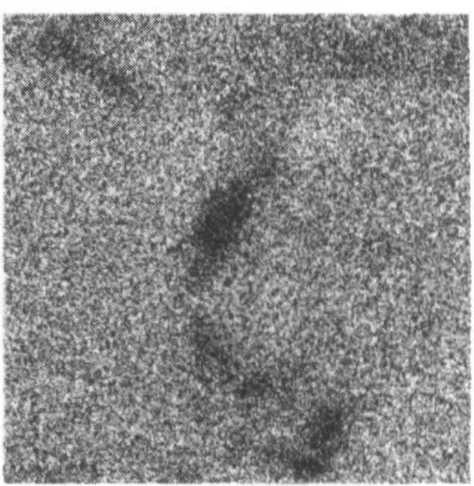

(c) $\mathrm{Cr}$

Fig.9 SEM-EDX image of sintered $\mathrm{Al}_{90} \mathrm{Cr}_{10}$ amorphous alloy with $\mathrm{Al}$ phase. In the $\mathrm{Al}$ (b) image and $\mathrm{Cr}$ (c) image, a white region indicates high contents of the each element. 